\title{
Current Practices on Solar Photovoltaic Waste Management: An Overview of the Potential Risk and Regulatory Approaches of the Photovoltaic Waste
}

\author{
Rishikesh Bajagain $^{1 \oplus} \cdot$ Gayatri Panthi $^{1 \oplus} \cdot$ Youn-Joo An ${ }^{2 \oplus} \cdot$ Seung-Woo Jeong ${ }^{1,+}$ \\ 'Department of Environmental Engineering, Kunsan National University, Gunsan, 54150, South Korea \\ ${ }^{2}$ Department of Environmental Health Science, Konkuk University, Seoul, 05029, South Korea
}

(Received November 6, 2020; Revised November 29, 2020; Accepted December 8, 2020)

\begin{abstract}
The use of hazardous metals like lead, cadmium in solar photovoltaics (PVs) are rapidly increasing which poses the risk to the environment due to potential release of these constituents. The main purpose of this review is to highlight the updated information on solar PV waste along with the present condition of efforts for recovery, country-wise regulatory approach or strategy on solar PV management and recycling. A brief literature review is assessed based on recently published articles and reports, which provides the readers a general overview on the solar PV waste management and regulations made by world leader countries in solar panels. This study discussed on the risk of hazardous chemical species releasing from PV modules and criteria of PV panel waste classification. Furthermore, the estimation of solar waste PV, its categorization, management approaches, country guidelines and recycling of waste PV panels, were mainly focused in this study. Apart from this, the major leaching tests carried out for waste classification and PV waste recycling in different countries are also discussed. Solar PV waste generally categorized as a general waste by the regulatory aspect, except in the EU, since PV panels in these countries are described as e-waste as stated in the Waste Electrical and Electronic Equipment (WEEE) Directive. To reinforce the recycling option, currently only Europe has mandated a strong regulatory guideline, however, other nations are preparing to set up particular system for solar panel waste management. In particular, this paper focuses on the potential risk caused by solar panels, data collection for PV waste and management approach like recycling. Besides, this review believes the basics of PV panel installation, management and recycling process which could recommend upcoming guidance for the public policymakers.
\end{abstract}

Keywords: PV Waste, Hazardous Species Leaching, Waste Management, Regulatory Guidelines, PV Recycling 


\section{Introduction}

From sun, we can get unlimited renewable energy for infinite time, so the solar energy is replacing other forms of energy like coal, petroleum, nuclear energy which are limited in amount, produce greenhouse gases and expensive. Solar energy is safe, reliable, environment friendly, economical and convenient to use. ${ }^{1)}$ At present, the solar photovoltaic (PV) technology is the rapidly emerging energy source around the world which is considered as renewable and environment friendly source of electricity. ${ }^{2)}$ During 2015-2017, the solar PV technology was demonstrated to be the only electrical energy generating technology that practiced for a constant growth in investment without any interruption. ${ }^{3)}$ Furthermore, the IEA projection showed that an approximately $15 \%$ capacity of PV should be raised annually from 2014 to 2030 to constrain global warming up to a small increment (within $2^{\circ} \mathrm{C}$ only) as of the level of pre-industrial epoch. ${ }^{4)}$

In 2015, the total capacity of established PV globally extended to $222 \mathrm{GW}$, which exceeded $400 \mathrm{GW}$ by 2017 and is projected to reach further to $4500 \mathrm{GW}$ by 2050 specially China, India, the US, Japan and Germany with expected high cumulative deployment rates. ${ }^{5-7)}$ In 2017, the PV installation in China was about $53.3 \%$ of worldwide capacity, while at the same time, there was a record solar tender declared in Saudi
Arabia. ${ }^{7)}$ In the USA, the annual growth rate of PV capacity in the last decade was increased by $65 \%$ (average). ${ }^{8)}$ Fig. 1 shows the global (leading country-wise) total installed capacity in 2017 and projected capacity for PV panel installation by 2022 along with annual growth rates. Also, total installed capacity of Thailand had reached about 2.7 GW by 2017.9) Among the top 20 countries, two countries (Egypt and Saudi Arabia) are supposed to have compound annual growth rates of more than $100 \%$ until 2022 , while the annual capacity for most of the leading countries will expected to get increase with two-digit rates. Furthermore, in the medium scenario estimated by Solar Power Europe ${ }^{7)}$, China is expected to add $209 \mathrm{GW}$, followed by India (78.4 GW), the US (62.6 GW), Japan (29.3 $\mathrm{GW}$ ), and Germany (20.2 GW). Whereas, the slowest growing market among the top 20 leading countries is the UK, which is projected for adding $2.1 \mathrm{GW}$ up to 2022 , with only $3 \%$ annual growth rate. ${ }^{7)}$

To utilize the energy from sun, various types of devices are developed, such as solar cell or photovoltaic cell (PV), which convert the solar energy into electricity. There are three types of photovoltaic panels; (a) 1st generation, known as crystalline silicon (C-Si); (b) 2nd generation, known as thin film (containing one or more than one thin layer of PV material, such as glass, stainless steel or plastic, on surface); and (c) 3rd generation, such as concentrator photovoltaics (CPV) and

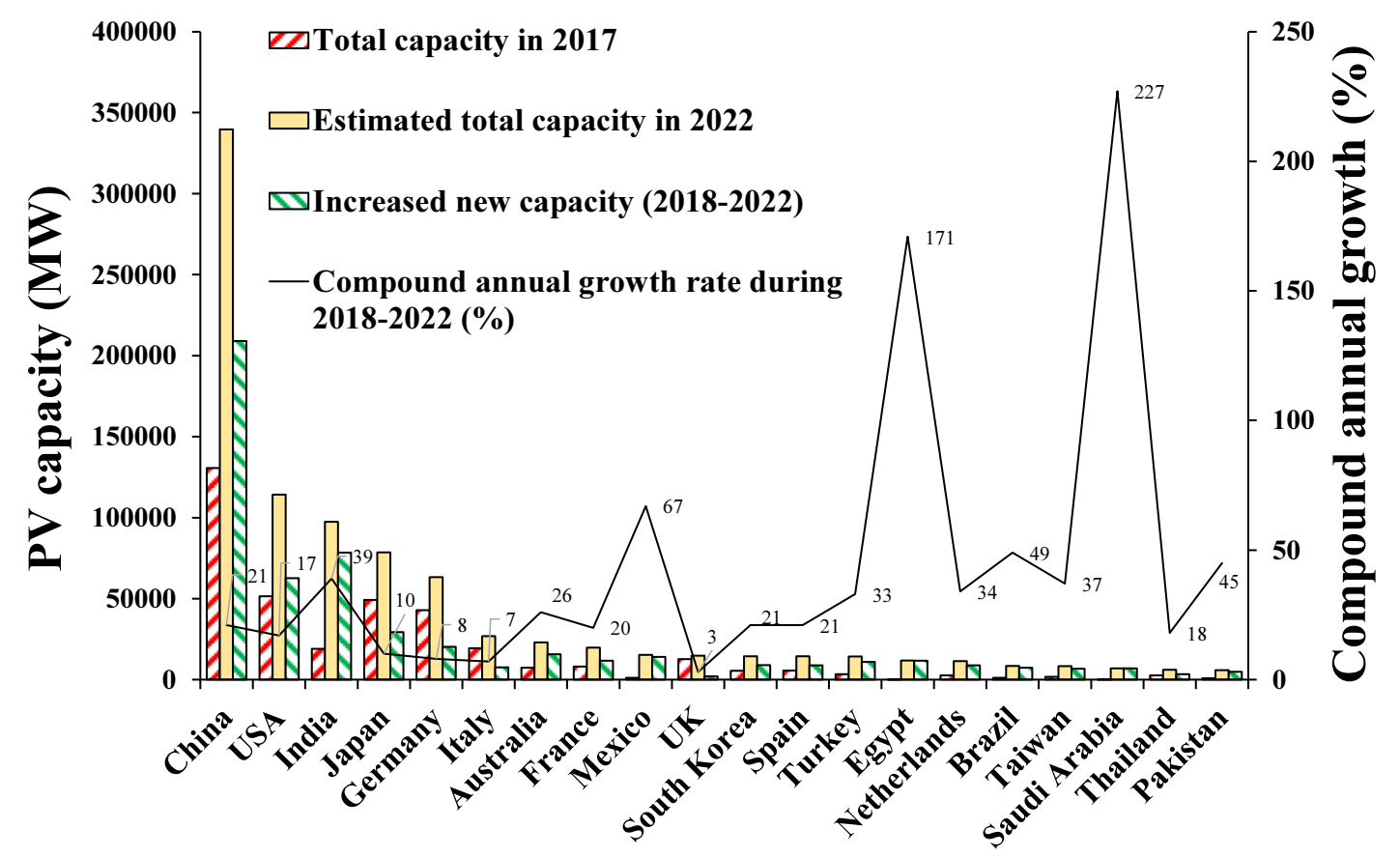

Fig. 1. Top 20 countries for global solar PV market. These data show an overall PV capacity that was installed by 2017 and an estimated 2022 total capacity in medium scenario with projected annual growth rate (figure generated from data provided in reference ${ }^{10)}$ ). 
emerging technologies. ${ }^{1,2,11)}$ In 2015, the allotment of worldwide PV production for $\mathrm{Si}$ PV was 93\% (69\%, polycrystalline $\mathrm{Si} ; 24 \%$, monocrystalline $\mathrm{Si}$ ), followed by CdTe (4\%); CIGS (2\%); and amorphous Si PV (1\%). ${ }^{12)}$ The c-Si PV contains following materials with their proportions; glass (about 76\%), polymer (encapsulant and backsheet) (10\%), aluminum (mostly the frame) (8\%), silicon (5\%), copper (1\%) and of silver, tin and lead (less than $0.1 \%$ ). ${ }^{6}$ The fraction of aluminum and polymers will decrease while glass is expected to increase as new technologies are adopted, this is due to dual-glass bifacial designs and frameless models. ${ }^{13)}$

Although the photovoltaic panels are renewable and long-term energy source that depend upon sunlight only and efficient in providing electricity to the users, however, the key issue is that it is not certain after their life cycle ends and what will happens in the future. ${ }^{14)}$ The human health and surrounding environmental complications can be prevented by keeping the solar waste constituents out of the landfill, which also protects the valuable assets for reuse. ${ }^{15)}$ However, most of the PV waste now ends up in landfill which can result in substantial environmental pollution concerns due to use of heavy metals/metalliods (e.g. Pb, Sn, Se, Te) in the PV modules. ${ }^{16}$ ) The hazardous materials used in the manufacture of solar panels are hard to recycle and can pollute the drinking water. Furthermore, if the valuable materials present in the PV modules are not recovered and the landfill option is recommended, it also makes additional costs.

Waste classification considers for the possible mobilization pathways of components and materials (such as leaching of components into groundwater, particulate matter entering into the soil) for various scenarios, such as reuse, recovery, recycling and disposal scenarios. The waste can be primarily categorized into different types based on various regulations, for example hazardous waste, non-hazardous waste and inert waste.6) However, most of the countries have categorized the solar panels into general or industrial waste. Currently, solar PV waste regulation is implemented by only the European Union (EU). In some other leading countries like the USA or Japan, the common waste guidelines may comprise of inspecting panel for harmful constituent along with prohibition or instruction of individual pathways such as consignment, curing, recycling and disposal. In this context, to assist the recycling, a powerful regulatory framework is established by EU only, however, most of the leading countries are just beginning to set up specific system for solar waste management.

The pictorial diagram of this research is presented in Fig. 2, which included the process of raw material extraction, PV panel manufacturing, their utilization and waste panel processing steps. Besides, the production of environmental pollution by the PV waste is also presented in the diagram. In order to resolve the environmental risk caused by solar panel waste, it is necessary to handle the EOL management system.

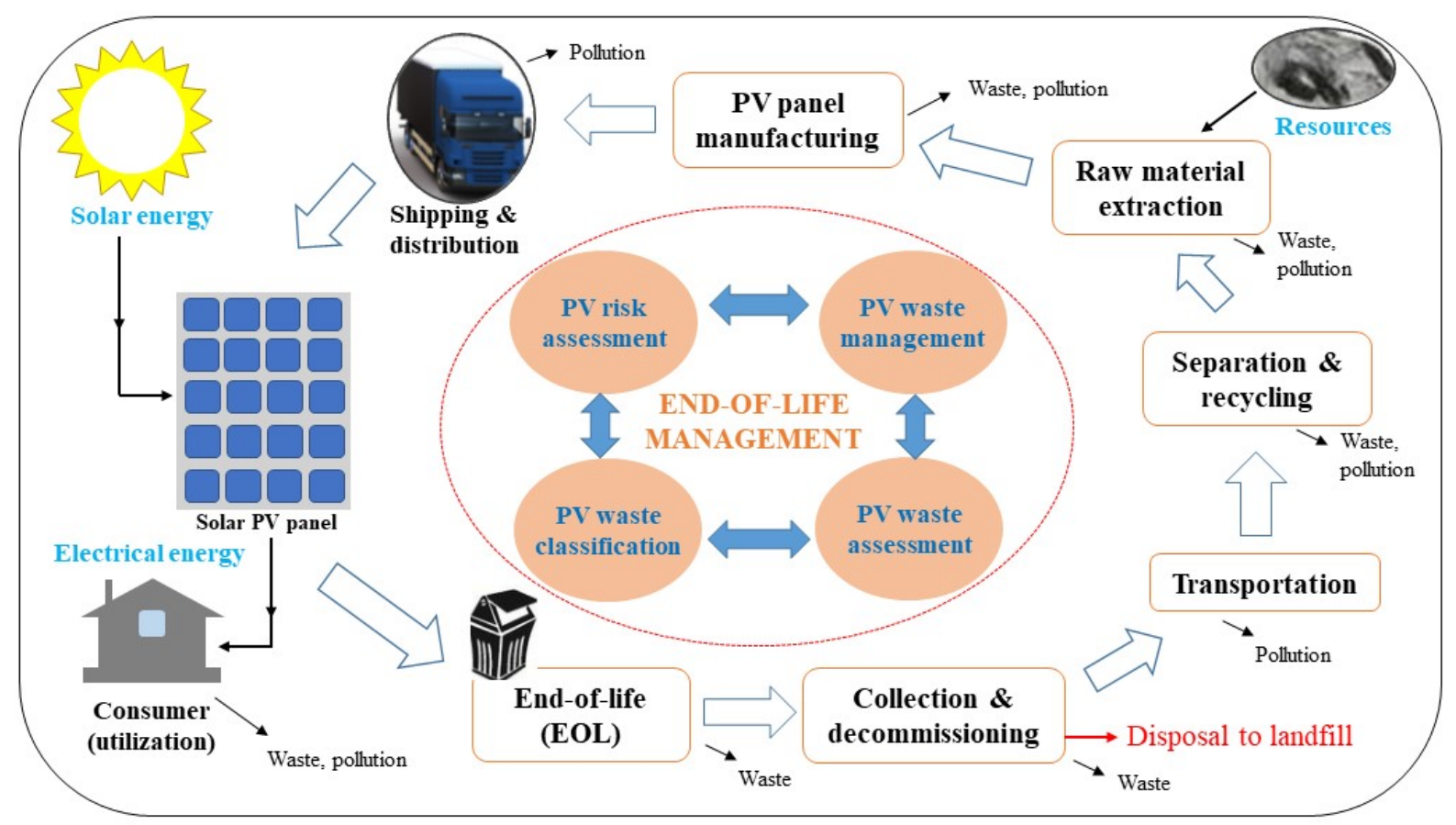

Fig. 2. Schematic diagram of this study showing comprehensive representation of manufacturing process to management process for solar photovoltaic system. 
The details of this study are described in following sections.

Since solar PV panels are using as a source of sustainable energy production and after their life cycle ends, they are also being able to be reused for the same or different purposes, thus the solar PV panels will be considered as the dual green products. Solar modules recycling strategies are under developing worldwide to reclaim the valuable materials and to minimize effect of solar waste, however, only a few percentage of materials can be recovered by existing recycling systems. ${ }^{16)}$ Consequently, there is an abundant opportunity for improvement in this area. Thus, the solar waste management is currently a developing sector, which needs additional investigation along with its progress. The main purpose of this study is to point out the updated information on solar PV waste and a summary of the current recovery efforts, country-wise regulatory approach or strategies on recycling and PV management. Another purpose of this review is to discuss about the risk of hazardous chemical species releasing from PV modules and criteria of PV panel waste classification. Furthermore, this review believes the fundamentals of PV panel installation, management and recycling which could recommend future instructions for policymakers.

\section{The potential risk with waste PV modules}

The rapid increase in number of waste solar panels has become challenging by the evolution of massive expansion and employment of solar energy technology. PV systems contain some hazardous substances and most of them contains heavy metals like cadmium, copper, lead, nickel, tin and zinc. ${ }^{17)}$ The use of hazardous metals like lead, cadmium in solar PVs are rapidly increasing which poses the risk to the environment due to potential release of these constituents. ${ }^{18)}$ Although the use of solar cells is very beneficial to us, however, some environmental concerns are recently increased about disposal after use and thereby leaching of hazardous components. ${ }^{11)}$ When there is damage in panels or glass crack, those substances can escape to the surrounding, although the effective panels are protected by using glass sealing and they are very secure. ${ }^{19)}$

The harmful chemicals generally present in photovoltaic cell comprise of cadmium telluride, copper indium selenide, cadmium gallium (di)selenide, copper indium gallium (di)selenide, lead, polyvinyl fluoride, hexafluoroethane. It is reported that about $80 \%$ of the raw silicon is lost during production of crystalline silicon from silicon and in this process, silicon tetrachloride is produced which is considered as one of the most toxic byproduct. ${ }^{20)}$ Besides, the emission of a chemical compound from solar panels, nitrogen trifluoride $\left(\mathrm{NF}_{3}\right)$, is significantly increases which is 17,000 times worse for the atmosphere compared to $\mathrm{CO}_{2}$ as a greenhouse gas for more than 100 years. $^{20,21)}$

In ordinary state, these toxic substances are not released out but when there is a defect on the system due to improper handling or installation or if there is a crack in the system, rain can penetrate inside the systems and heavy metals may be leached out. ${ }^{22)}$ Celik et al. ${ }^{17)}$ reported that the exposure of cells to the moisture leads to the metal emission during utilization period which causes negative impact on the environment. Furthermore, environmental impacts due to disposal after use has been questionable. In contrast, International Energy Agency PV Power System Programme (IEA PVPS) suggests that the solar PV can be landfilled safely and do not pose landfill health threats, though PV modules can be recycled. ${ }^{23)}$ However, it can be harmful to the ecosystem representing the substantial risk to health and the environment when the toxic components from PV waste are released into the surroundings. ${ }^{16,24)}$ For example, lead $(\mathrm{Pb})$ and cadmium $(\mathrm{Cd})$, used in solar panels, are contaminant of concern because of their highly toxic nature. Exposure to the toxic substances like $\mathrm{Pb}, \mathrm{Cd}$, Ni can cause cancer, kidney, liver, lungs and brain damage, which are toxic to blood, prostate, respiratory system and also recognized for reducing reproduction, increasing behavior problems as well as humans and wildlife death. ${ }^{24-28)}$ In addition, $\mathrm{Cu}$ also can bring about injury of kidney and liver; while selenosis, a disease of the respiratory system can be caused by selenium (Se), along with hair loss and nail brittleness; and strontium (Sr), when consumed in large quantities, can show a negative effect during developing bone. ${ }^{24)}$ Thus, the risk of these hazardous species contained in solar PV systems should be assessed for the surrounding environment.

\section{Solar panel waste assessment}

With the growth of solar energy deployment, the global waste production regarding PV panel is increasing every year. This is because life time of solar cells is normally expected as $25-30$ years for generating electricity and may even reach up to 40 years for high quality PV panels. ${ }^{14,29)}$ As compared to the nuclear power plants, PV panels can make up 300 times greater noxious waste per unit energy, which would reach up to the height of two Mt. Everest $(16 \mathrm{~km})$ over the next 25 years if same amount of electricity is being produced in $2016 .^{21)}$ The global projection of PV panel waste volume based on existing 
Table 1. Worldwide projected cumulative waste volumes of PV panels (tons). The cumulative PV waste volume was estimated by IRENA and IEA-PVPS. ${ }^{\text {) }}$

\begin{tabular}{ccc} 
Year & Regular loss & Early loss \\
2020 & 100,000 & 850,000 \\
\hline 2030 & $1,700,000$ & $8,000,000$ \\
\hline 2040 & $15,000,000$ & $32,000,000$ \\
\hline 2050 & $60,000,000$ & $78,000,000$ \\
\hline
\end{tabular}

Table 2. Amount of solar panel waste (tons) in world. Table generated from data provided in reference. ${ }^{14)}$

\begin{tabular}{|c|c|c|c|c|c|}
\hline Country/ year & 2016 & 2020 & 2030 & 2040 & 2050 \\
\hline Australia & 900 & 2,000 & 30,000 & 300,000 & 900,000 \\
\hline Brazil & 10 & 40 & 2,500 & 18,000 & 300,000 \\
\hline Canada & 350 & 700 & 13,000 & 150,000 & 650,000 \\
\hline Chile & 150 & 250 & 4,000 & 70,000 & 400,000 \\
\hline China & 5,000 & 8,000 & 200,000 & $2,800,000$ & $13,500,000$ \\
\hline Denmark & 80 & 100 & 4,000 & 40,000 & 130,000 \\
\hline Ecuador & 10 & 15 & 250 & 5,000 & 25,000 \\
\hline France & 650 & 1,500 & 45,000 & 400,000 & $1,500,000$ \\
\hline Germany & 3,500 & 20,000 & 400,000 & $2,200,000$ & $4,300,000$ \\
\hline India & 1,000 & 2,000 & 50,000 & 620,000 & $4,400,000$ \\
\hline Indonesia & 5 & 45 & 5,000 & 30,000 & 600,000 \\
\hline Italy & 850 & 5,000 & 140,000 & $1,000,000$ & $2,100,000$ \\
\hline Japan & 7,000 & 15,000 & 200,000 & $1,800,000$ & $6,500,000$ \\
\hline Malaysia & 20 & 100 & 2,000 & 30,000 & 190,000 \\
\hline Mexico & 350 & 850 & 6,500 & 55,000 & 630,000 \\
\hline Morocco & - & 10 & 600 & 4,000 & 50,000 \\
\hline Nigeria & 150 & 250 & 2,500 & 50,000 & 400,000 \\
\hline Russia & 65 & 100 & 1,000 & 20,000 & 150,000 \\
\hline Saudi Arabia & 200 & 300 & 3,500 & 70,000 & 450,000 \\
\hline South Africa & 350 & 450 & 8,500 & 150,000 & 750,000 \\
\hline South Korea & 600 & 1,500 & 25,000 & 300,000 & $1,500,000$ \\
\hline Turkey & 30 & 100 & 1,500 & 20,000 & 200,000 \\
\hline UAE & - & 50 & 3,000 & 20,000 & 350,000 \\
\hline UK & 250 & 650 & 30,000 & 350,000 & $1,000,000$ \\
\hline Ukraine & 40 & 150 & 5,000 & 50,000 & 210,000 \\
\hline USA & 6,500 & 13,000 & 170,000 & $1,700,000$ & $7,500,000$ \\
\hline
\end{tabular}

and future annual installations is summarized in Table 1. Waste PV module could make up to 60 to 78 million tons $(10 \%$ of all e-waste produced) worldwide by $20500^{5,30)}$ The global projection for volume of upcoming PV panel waste is investigated and compared with two scenarios i.e. (i) regular-loss, by assuming a life span of 30 years for panels with no early attenuation; and (ii) early-loss, by accounting earlier defect during infant, middle-life and wear-out of the 30-year lifetime. ${ }^{\text {) }}$

It was estimated that an approximately 11,000 tons of $\mathrm{Pb}$ and 800 tons of $\mathrm{Cd}$ were outspread by 2016, which was assumed from the volume of installment and power-related mass. ${ }^{20)}$ In the EU, WEEE has established ambitious collection rates targets for e-waste and an assessment reported that approximately 10 million tons of them (or about $20 \mathrm{~kg}$ per capita) will be separately collected in $2020{ }^{31)}$

Table 2 presents the amount of solar panel waste that is generated and will be produced by world leading countries from the period of 2016-2050. It can be seen that until 2030, Germany will lead the waste PV panel production by 0.4 million tons $(\mathrm{mt})$, followed by Japan $(0.2 \mathrm{mt})$, China $(0.2 \mathrm{mt})$, USA $(0.17 \mathrm{mt})$ and Italy $(0.14 \mathrm{mt})$. However, China will 
Table 3. Solar PV waste classification using leaching tests in different countries. $^{32)}$

\begin{tabular}{|c|c|c|c|}
\hline & Japan & Germany & USA \\
\hline Leaching test & $\begin{array}{l}\text { MOE Notice 13/JIS K 0102:2013 } \\
\text { method (JLT-13) }\end{array}$ & $\begin{array}{l}\text { DIN EN GIS standard } \\
12457-4: 01-03\end{array}$ & US EPA method 1311 (TCLP) \\
\hline Sample size $(\mathrm{mm})$ & 5 & 10 & 9.5 \\
\hline Extraction fluid & Distilled water & Distilled water & $\begin{array}{l}\text { Sodium acetate/acetic acid ( } \mathrm{pH} 2.88 \text { for alkaline waste; } \\
\qquad \mathrm{pH} 4.93 \text { for neutral-acidic waste) }\end{array}$ \\
\hline $\begin{array}{l}\text { Solid:fluid ratio } \\
(\mathrm{w} / \mathrm{v})\end{array}$ & $1: 10$ & $1: 10$ & $1: 20$ \\
\hline Agitation (rpm) & End-over-end (200 rpm) & End-over-end (5 rpm) & 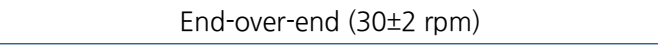 \\
\hline $\begin{array}{l}\text { Test temperature } \\
\left({ }^{\circ} \mathrm{C}\right)\end{array}$ & 20 & 20 & $23 \pm 2$ \\
\hline Test duration (h) & 6 & 24 & $18 \pm 2$ \\
\hline
\end{tabular}

MOE: Ministry of Environment; GIS: German Institute for Standardization; EPA: Environment Protection Agency

overtake the generation of PV wastes by 2040 with 2.8 million tons followed by Germany, Japan, USA and Italy. Further, a rapid acceleration in waste volume in all countries is estimated by 2050 , as such China will held number one position with 13.5 million tons and USA, Germany, Japan will follow China with 4.3-7.5 million tons of wastes. At the same time, India will be a new big PV waste generating country with 4.4 million tons and some other countries such as South Korea and UK will produce more than one million tons of PV waste. With less than one million PV waste, Australia, Chile, Canada, Indonesia, Mexico, South Africa, Saudi Arabia, and UAE will also contribute a higher production by 2050 .

\section{PV panel waste classification criteria}

Leaching tests are generally carried out for the classification of hazardous or non-hazardous waste. To be classified as non-hazardous waste, distinct threshold values of the waste substance have been allowed by various authorities (for example Japan, USA and Germany) for acceptable leachate concentration. Various leaching test methods for PV waste characterization in different countries are summarized in Table 3.

The research for leaching test is bounded to the major pollutants for each of the three largest groups of solar panels i.e. c-Si, CdTe and CIGS. 22,24,32-37) However, other types of solar panels, for example, amorphous silicon (a-Si), perovskite solar cell (PSC) and organometallic solar cells have not been studied well and it is just in beginning phase. ${ }^{11,38,39)}$ Moreover, the current research is not focused on leaching of each constituents (mainly hazardous metals, metalloids, organics, gaseous and other wastes) present in all types of solar panels. Only the EU offers legislative structure for producer responsibility of PV panels through WEEE Directive
2012/19/EU and thus the gathering, transporting and recycling of PV panels (with reaching EoL) are managed in each EU country by 2014. However, at present, there is dearth of specific protocols for PV panels in the leading nations with rapid mounting of PV installation, for example China, the US, Japan, India, Australia, where the PV waste is handled with a common regulatory outline for hazardous and non-hazardous solid waste or WEEE. ${ }^{16)}$

\section{PV panel waste management: country wise regulatory approach around the world}

\subsection{Collection of PV waste and extended producer responsibility}

Although the volume of waste solar panel is currently lower, which is not enough to fascinate recyclers/producers for collection and recovery of materials, however, the amount of PV waste disposed into the landfill can be reduced by building regulation and collection programs. The critical factors for the industry to keep the economical operation are collection centers and networks amongst stakeholders. ${ }^{40)}$ Some PV companies (such as First Solar, BP Solar, SolarWorld AG, PV Cycle) have started PV waste collection programs. ${ }^{41)}$ For example, First Solar deposits sufficient fund separately which is required to collect and recycle the solar panels in future. The first step (one of the three steps) of collection and recycling program of First Solar Company is to register individual module which is sold by the company. All of the packing and shipping costs associated with the collection of module after decommission are paid by the company. It is reported that the cost of collecting materials (comprise of fuel, labor and logistic costs) have greater influence on profits compare to perform recycling, processing and capital costs. ${ }^{42)}$ A study demonstrated that rate 
Table 4. Analysis of the structure of cost/revenue for three recycling scenarios. Table generated from the data provided in the reference. ${ }^{42)}$

\begin{tabular}{|c|c|c|c|}
\hline & Single pilot plant & Full pilot plant & Automated plant \\
\hline Capacity & 1876 module ( 17 ton) & 185 ton/year & 20,000 ton/year \\
\hline Processing type & Manual separation & Manual separation & Automated separation \\
\hline Recovery rate & $85 \%$ & $85 \%$ & $96 \%$ \\
\hline Capital cost (\$/month) & $-1,111$ & $-1,111$ & $-15,495$ \\
\hline Collection cost ( $\$ /$ month) & $-1,893$ & $-1,727$ & $-171,832$ \\
\hline Processing cost ( $\$ /$ month) & $-14,321$ & $-16,215$ & $-87,658$ \\
\hline Revenue (\$/month) & 9,816 & 8,953 & 899,740 \\
\hline Revenue/total-cost ratio & 0.56 & 0.47 & 3.27 \\
\hline Cost: revenue percentile fraction in overall economy & $63.8 \%: 36.2 \%$ & $68 \%: 32 \%$ & $23.4 \%: 76.6 \%$ \\
\hline
\end{tabular}

The costs are presented in negative value.

of rise in revenue was found to be higher than the rate of collection and process costs growth as increase in the annual incoming waste volume (see Table 4). ${ }^{42)}$ It showed that the manual separation used in single and full pilot plants are not cost-effective recycling options because of labor intensive work.

The extended producer responsibility (EPR), also called as Product Stewardship, is one of the policies that deals with the problems related to e-waste. EPR is an environmental strategy which is promoted by the Organization for Economic Cooperation and Development (OECD) that hold out the responsibility of producers for products to the post-consumer phase of the life cycle of product. ${ }^{43)}$ It permits the processing and disposal charge to be integrated into the overall cost of product. The conception of EPR states that life cycle impacts of a product are noticed as the producers' and manufactures' responsibility that produce those things. ${ }^{44)}$ The EPR comprises of two characteristics, i.e. to shift responsibilities towards manufacturers for the period of products' life cycle; and to provide the incentives to manufacturers for incorporating environmental concerns straight in product design step. ${ }^{43)}$ The EPR policy has been implemented by some countries, for e.g. Japan, Switzerland and the Netherlands, and they focused on big household equipment, electronic equipment and information technology appliances respectively. EU WEEE Directive mandatorily includes every manufacturers distributing solar panels to Europe to invest collection and recycling fund. ${ }^{5)}$ The responsibility for treating PV panels must be accepted by manufacturers and importers in EU or large fines would be subjected to them. ${ }^{5)}$ The term 'Producer' comprises of manufacturer, distributor, reseller, importer and distance seller of solar panels or any authorized person that established in a particular member state, and placing solar panels onto the market. ${ }^{45)}$ Also, some states in USA have their PV collection program, such as Washington State started product stewardship program in 2017 while New York State started "Solar Panel Collection Act" in 2018. However, this policy is not implemented by federal government of USA for giving authority that necessitate the implementation of EPR take-back plans to national level. ${ }^{40)}$

A study carried out by McDonald and Pearce for the investigation of potential requirement for solar panel recycling policies by evaluating existing recycling procedures. ${ }^{41)}$ Results showed that without suitable policies, the economic incitement was not favorable for most PV recycling approach and no significant difference was found between landfill and recycling expenditures. Now, the voluntary PV recycling have started by some PV producing industries, however, it is stated in the literature that these initiatives may be motivated by environmental responsibilities rather than financial profit. Also, the authors concluded that the encouragement of producer responsibility is desired not only for PV producing industry but also in the entire energy sector. Though some other policy methods (for e.g. mandated customer recycling) are existed for ensuring an appropriate disposal of harmful materials containing products, nevertheless it is much likely advantageous to use producer responsibility for solar panels since the government is facilitating to support the industry. So, the use of producer responsibility for ensuring appropriate disposal of solar-related harmful waste will secure the consumers without forcing with this burden. ${ }^{41)}$ Therefore, it is essential to consider to have EPR program for facilitating the formation of market for solar panel waste collection.

\subsection{An overview on PV waste management approaches}

Currently, there is dearth of regulation and not enough policies 
made by leading countries in world for PV panel and running without having disposal plans. ${ }^{5,46}$ In most of the countries around the world, the photovoltaic waste are included under the e-waste or hazardous waste. ${ }^{14,18)}$ Since, a huge amount of solar waste is produced every year which is difficult to recycle and the problem caused by its disposal will explode harshly in few decades which will deteriorate the environment. ${ }^{47)}$ Waste PV module could make up to $60-78$ million tons worldwide by $2050^{5,30)}$ and yet, globally working recycling procedure for PV waste is not entirely advanced. ${ }^{30)}$ At present, they are just dumped away in the landfill without handling with care, so their active material may be released in the environment that are hazardous for whole ecosystem. ${ }^{16,48)}$ Currently, only EU implemented solar waste regulation on manufacturer accountability for the gathering and recovery of solar panels. ${ }^{5,49)}$ The general electronic waste guidelines of developed countries, such as the US or Japan, still governed the toxicity characterization, construction and prohibition of PV waste and disposal pathway. ${ }^{18)}$ Thus, sufficient strategies and directions or guidelines must be employed for solar panels EoL treatment with effective processes.

For EoL PV panel waste management, there are several approaches that have been developed, beyond general waste protocols. For example, the life cycle methodology for waste management approaches consists of raw materials extraction, manufacturing, use, disposal or reuse, recycle and recovery. Society, consumers and producers are three main contributors who should be responsible for PV waste management task (waste generation, treatment of collected waste and disposal). ${ }^{6}$ There are three main targets (i.e. collection, recovery and recycling target) that come to the key operator for waste management protocols and PV panel waste requires the balancing of these factors (targets) to develop a PV management scheme.

In 2016, IRENA and IEA-PVPS summarized the common essence of PV waste management. ${ }^{6}$ The illustrations depicting voluntary, public-private-partnership and regulated methods are also included. The voluntary approach can be established by manufacturers for individual voluntary takeback the malfunctioned panels for recycling on requisition and these programs can be managed by the manufacturer or via recycling facility provider. As set up by PV Cycle in 2007, the public-private approach may include 'bring-in' and 'pick-up' scheme established on the essence of public-private-partnership amidst industries and European regulators. However, it is already mentioned above that only EU is the authority which established particular guidelines and regulations to address the PV EoL management. ${ }^{6}$ Electronic waste regulations, first developed by EU has included collection, retrieval and recycling targets for PV and the WEEE Directive mandatorily involves every manufacturers distributing solar panels to Europe to invest collection and recycling fund. ${ }^{5)}$ In this chapter, this study reviewed the present tactics followed by leading countries for solar waste management.

\subsection{Regulatory classification of PV panel waste}

Solar PV waste mostly comes in the common waste category, yet, from a regulatory viewpoint. ${ }^{14,18)}$ However, the European Union (EU) categorized the PV panels as e-waste in the Waste Electrical and Electronic Equipment (WEEE) Directive. The title 'electrical and electronic equipment' or EEE is described as equipment (tool) created for usage with a voltage, no more than $1,000 \mathrm{~V}$ for alternating current and $1,500 \mathrm{~V}$ for direct current, or tool depending on electric currents or electromagnetic fields for proper working, or tool for generating that currents, or tool for the transferring currents, or tool for measuring currents. According to WEEE directive, glass and metals are separated by crushing the panels. Material like silver or copper are recovered by using different methods (chemical and thermal).

\subsubsection{Australia}

Until September 2018, total installation of solar panels in Australia has traversed from 1.95 million panels which is equal to $10131.3 \mathrm{MW}^{50)}$ It is estimated that more than 0.1 million and about 0.8 million tons of solar panels by the end of 2035 and 2047 respectively, will enter Australia's waste stream. ${ }^{15,50)}$ However, the challenging issue is the dearth of committed facilities that can reclaim the precious materials. In Australia, the handling and discarding of PV waste vary through each territorial region. In Victoria, the solar waste has been regarded as e-waste and commit for banning from landfill since 2014. Although there are many PV panel recycling facilities are existing in Australia, nevertheless, they are able to recover and retrieve only a small fraction of a panel (up to $17 \%$ by weight) especially aluminum frame and junction box. That means, $83 \%$ of the remaining solar PV's waste materials such as silicon, polymer back sheets, glass have not recycled. However, for proper management of PV products, a national approach is now being developed. ${ }^{15)}$ In between 2014 to 2019, the national working group made recommendation for management of solar panel waste which will include manufacturers, dealers and customers taking accountability for the effects on environment 
and health. The three main options are exploring which accessible via Australia's domestic product stewardship structure, they are industry-led, co-regulatory and mandatory stewardship schemes. As Australia is expected to be facing about one to eight million tons of dismantled PV by 2060, the retrieval of raw ingredients can give rise to worth making of approximately 1.2 billion dollars. ${ }^{50)}$ Moreover, around 50 million new solar panels can be manufactured from regained substances with same arrangement or they can be used to produce new product.

\subsubsection{India}

India needs to alleviate energy poverty and face expanding electricity requirement resulting from the quick economic development. Thus, the installation and deployment of PV panels in India are rapidly growing. Currently, India is amid top-10 photovoltaic marketplace in the world. It is estimated that the cumulative PV waste projection of about 50000 and 4.4 million metric tons by 2030 and 2050 respectively. ${ }^{14)}$ In India there is no particular guidelines considering solar panels waste and the PV waste is dealt with common waste protocols. $^{18,46)}$ The waste is managing on the basis of 2016 Solid Waste Management Rules and the Hazardous and Other Waste Rules. ${ }^{51)}$ The regulation made in 2016 i.e. E-waste (Management and Handling) Rules which comprise of prerequisites to be common e-wastes and control on using toxic materials in electronic products, but, those directions are implemented to household electronics only and not for solar panels. ${ }^{46)}$ The USEPA waste characterization technique, TCLP, has been included in recently amended Hazardous Waste Rules, and that requires authorization from the State Pollution Control Board. In addition, India already established an infrastructure for industrial-scale e-waste recycling but it covers only household electronics and not for the PV modules. ${ }^{51)}$ The increasing growth rates of PV panel deployment will most likely lead to waste regulations in the future.

\subsubsection{Taiwan}

The accumulative installed capability of renewable energy of Taiwan in 2018 was 6246 MW (11.91\% of overall installed volume for electricity yield) and the produced renewable energy was $12733 \mathrm{GWh}\left(4.7 \%\right.$ of entire power yield). ${ }^{52)}$ The targeted accumulative installation capability of renewable energy by 2025 is $27 \mathrm{GW}$ (20\% of overall power yield) for achieving nuclear-free Taiwan. For this target, the desired volume of installed photovoltaics is about $20 \mathrm{GW}$. The estimated cumulative waste solar panels in 2018 was about 2836 metric tons. The speedy growing PV panel installation has got alarming although the proportion of waste panel to the installed PV modules is small. Since, recycling workshop are not available for the discarded PV panels, almost all of them obtained from household, PV factory and PV business ventures in Taiwan have been collected and sent to manufacturers or gathering centers. ${ }^{52)}$ Thus the dealing with waste panels for avoiding possible contamination becomes a major issue. However, after collecting waste panels that are thrown away, they only examine their performance and delivered to other nations to use again. Otherwise they have delivered to recycling workshop to disassemble aluminum frames and e-waste that is left is exported to other nations for further recovery. ${ }^{52)}$

\subsubsection{China}

The PV industry of China is larger than any other country. Compared to USA, there are two times more working PV panels that could make 14-20 million tons of PV waste by 2050, which could be up to 2000 times of Eiffel Tower's mass. ${ }^{6,21)}$ However, to date, there is no definite EoL treatment obligation in China and they are not comprised of waste electric and electronic-wares. ${ }^{6,18,46)}$ The Waste Electrical and Electronic Product Recycling Management Regulation was passed by State Council in 2009, which is effected in 2011 that needs the collection of e-waste and recycled through central processing method. ${ }^{51)}$ The PV manufacturers can gather and recycle by themselves or hand over to dealers, service centers or recyclers and invest to eligible organization for recycling or dumping. Although, China does not have an advanced recycling industry for PV waste due to low volume of waste in the present days, it has funded $R \& D$ on solar panel recycling techniques. They are focusing for two recycling techniques for crystalline silicon PV based on National High-tech R\&D Programme PV Recycling in China and Safety Disposal Research.

\subsubsection{Japan}

Japan assured the scale of electric power produced by using renewable energy source and distributed to the network by introducing a "feed-in-tariff" in 2012 and due to which PV panel installation is rapidly increased. As a result, solar modules in Japan will make a major waste problem when entirely installed panels once getting own EoL. The cumulative waste could amount to between 0.2 and 1 million ton in 2030 and could reach 6.5-7.6 million ton by 2050 . $^{6}$ Japan has no precise 
schemes and directories for treating EoL PV panels ${ }^{18)}$, however numerous political movements and R\&D events have been facilitating to construct the foundation for retrieval and recycling process. ${ }^{6}$ ) A report made a roadmap in 2015 (June), to approve a strategy for collection, recycling and appropriate treatment. In this strategy, technology R\&D marketing is also included as well as designing with environment favoring, disassembling procedures, shipping, handling, and advertising to customers. ${ }^{53,54)}$ In addition, for proper disposal of waste PV modules, the Japan Photovoltaic Energy Association (JPEA) in 2017 issued voluntary protocols. ${ }^{16)}$ The PV modules manufactures and distributors are requested to give information about the material composition present in the items and also the waste dumping institutions need to be informed. Moreover, the industry must follow the procedures that intensely suggested by JPEA. The development and setup of guideline for proficient and secure recycling of solar panel is still in the course, though, Japan has been proceeding well for the development and testing methods to recycle the PVs. This would be the advantageous for Japan in future when accumulating a massive amount of waste $P V^{46)}$ It is reported that about 19 years would be taken to end recycle of entire PV by Toshiba Environmental Solutions, when considering the Japan's PV waste yielding until $2020 .^{21)}$

\subsubsection{South Korea}

The South Korean government has set up a goal for rapid expansion of renewable energy from electric power sharing up to $20 \%$ until 2030 and about $63.8 \mathrm{GW}$ of these energies is planned to install for achieving this goal. ${ }^{55)}$ In this context, $57 \%$ of the total capacity added would be accounted by solar energies. South Korean solar power would reach from 5.3\% of total capacity (or $5.7 \mathrm{GW}$ ) in 2017 to $29.7 \%$ of total capacity (or $36.5 \mathrm{GW}$ ) in 2030 by rising at a rate of $15.4 \%$ per year through that period. ${ }^{55)}$ The cumulative PV waste in South Korea is estimated to be 25000 metric tons by 2030 and 1.5 million tons by 2050 (see Table 2). ${ }^{14}$ However, the status of PV module operation and the waste generated from past PV installation are not currently monitored. South Korea does not have their particular procedures or directives that can directs handling of PV waste ${ }^{46)}$, but, the export of hazardous waste is controlled without approval from the importing country. ${ }^{18)}$ Republic of Korea has recently begun to discuss about solar panel wastes and classified them as industrial waste. Recently, the PV waste is comprised within one of industrial wastes in Annex Table 4 of Article 4.2 of South Korea's Enforcement Rule of
Wastes Control Act (Act No. 14783). The Article 4.2 defines comprehensive categorizations of waste and potential recyclables. According to Waste Control Act (Article 17), the producers of industrial waste have been requested for appropriate treatment of the waste and for lowering the waste volume by establishing waste-decreasing services, as well as advancing the techniques, and recycling. In 2016, two new projects had lunched to recycle the solar modules. One of them is $\mathrm{R} \& \mathrm{D}$ project, which is to demonstrate recycling method through development of recycling center (capacity of two tons/day). The another is non-R\&D project, which is to establish the PV recycling facility in South Korea for waste module management. ${ }^{56)}$ Ministry of Trade, Industry, and Energy, in 2017, had declared for construction of solar waste recycling center in North Chungcheong Province, South Korea. $^{55)}$

As similar to above mentioned countries, the other Asian countries, which are progressing on the PV installation on these days, will also produce significant volume of PV waste and do not have proper regulation. For example, in Thailand, the growth rate for solar installation was 50\% in 2016 than in previous year, which comprised of almost $76 \mathrm{GW}$ solar power installation. When counting more than $1 \mathrm{GW}$ PV installment, Thailand was occupied in the top $7^{\text {th }}$ position (in world) for most installed PV in 2016. ${ }^{9)}$ Thailand will have produced 5000 tons of waste by 2025 and by 2030 ; it will produce 8,000 tons (minimum) of PV waste annually, however the present strategy in Thailand is to landfill the waste panels. ${ }^{9}$

\subsubsection{United States of America (USA)}

The growing solar market in USA (by 2016) indicated that PV can be spread rapidly, which can be surpassed to accumulative PV capacity of $135 \mathrm{GW}$ by $2030 .{ }^{8)}$ After surpassing by only China, USA is anticipated for having $2^{\text {nd }}$ largest accumulative PV panel waste by 2050 . The US PV market has been growing rapidly since the mid-2000s and total accumulating waste is estimated as $0.17-1$ million tons in 2030 and perhaps it will rise by seven times to reach 7.5-10 million tons until 2050. ${ }^{6}$ In the USA, PV panels have to be disposed under the Resource Conservation and Recovery Act (1976), which is the legal structure for management of hazardous and non-hazardous solid waste ${ }^{5,6,46)}$. This is because USA has not mandatory guidelines for gathering, handling, recycling or waste disposal of solar panels. The hazardous wastes are classified into two groups, i.e. 'characteristic hazardous waste' and 'listed hazardous waste'. The 'listed hazardous waste' 
denotes to actual recording of particular kinds of hazardous waste. The PV panels must be assessed under characteristics hazardous waste methods (US Environmental Protection Agency Method 1311 Toxicity Characteristic Leaching Procedure (TCLP)), because PVs have not been included in 'listed hazardous waste'. TCLP method is employed to assess whether the leachate obtained from waste samples have contaminating species surpassing the regulatory limits. Furthermore, different states in the US can practice other leaching techniques, for example, California use waste classification based on 'total threshold limit concentration' and 'soluble threshold limit concentration'.

In the US, yet there is nothing mandated at the national level, however, some states are making an effort for getting the necessary recycling approach. Washington is the $1^{\text {st }}$ state for passing the solar stewardship bill (ESSB 5939) in July 2017, in which the manufacturer require to have PV recycling plans for their own PV-wares. ${ }^{13,46,57)}$ Besides, the manufacturers cannot sell the PV panels in this state after January 1, 2021 which do not offer a recycling package or plan. Likewise, Senate of New York had similar act in 2018 (bill S2837A), in which PV panel producing companies are required to gather EoL panels to recycle them. ${ }^{13)}$ In 2015, California passed SB 489 which encourages safe disposal of old panels and designated PV panels as universal hazardous waste like widely used TVs and batteries. ${ }^{58)}$ According to California act, the widespread waste cannot be landfilled or trashed, however, procedures are not provided properly for recycling PV panels. ${ }^{13)}$ Nowadays, California considered this bill (SB 489) as a regulation and in 2017, a public announcement was programmed for rulemaking, which stated that it would go on operation in one year. ${ }^{46}$

\subsubsection{European Union (EU)}

The Europe has recognized the influence of solar waste in environment and thereby manufacturer accountability was governed to dispose and recycle PV modules appropriately. The PV producers, which sell in Europe begun to develop preliminary PV life cycle management conceptions, the most well-known illustration is pan-European PV CYCLE. ${ }^{\text {) }}$ However, the execution of voluntary approach (i.e. pan-European PV) became very difficult for long-term manufacturer accountability because of higher deploying rate, increasing production capabilities and rising PV demand universally and this directed to a quick internationalization and commoditization of distributing chains. Due to this reason, a regulation is needed for ensuring all market contributors to protect the durable EoL gathering and recycling for solar waste. ${ }^{59)}$ The novel WEEE Directive (Directive 2002/96/EC) was firstly established and came into effect for February 2003, however it was verified to be not enough to challenge the rapidly growing and varied wastes pattern. ${ }^{60)}$ The major purpose of the EU regulatory outline made via WEEE Directive is to address the e-waste management, including waste PV by balancing the advantages and disadvantages of various approaches.

In 2012, an amendment was made in this directive (2012/19/EU), with including particular outline for handling solar panels, and the recently amended WEEE Directive came into force in same year. ${ }^{61)}$ Again, another legal framework was included into the revised directive in 2014 for solar waste which must be executed by the European Union members. To collect and treat the solar panel according to the directive, all of the members in EU are thus nowadays mandated for developing the system. Since, the amended WEEE Directive is established that was based on the concept of extended-producer-responsibility, manufacturers are responsible for collecting, treating and checking expenses and thus they need to satisfy a definite number of requirement and responsibility. ${ }^{6}$ These responsibilities are as follows; financial responsibility, reporting responsibility and information responsibility. For managing PV waste properly, the European Commission (EC) had prepared a general tool that are requested to EU nations for estimation and submission of the generated PV waste by each country. The revised Directive has set the annual collection targets of $65 \%$ (by weight) for all appliances placed on marketplace or $85 \%$ of generated waste, which is effective by 2018 . The solar waste must discard and treat appropriately because the waste shipping in Europe is forbidden. Thus, recycling of solar panel constituents is promoted by this prohibition, not only the financial, ecological and social implications. ${ }^{5)}$

In Germany, PV paid 6\% of overall use of electricity (in 2015), with an entire installation volume of nearly $40 \mathrm{GW}$ spread in 1.5 million solar plants. For two successive decades, the world's biggest PV marketplace was Germany and turn into the second position when China overtook it in 2015. ${ }^{6}$ The regular-loss and early-loss scenario was forecasted in the range of 0.4 to 1 million ton and 4.3-4.4 million ton by 2030 and 2050, respectively. The first country for implementing EU Directive is Germany (in 2015), which add the solar waste directive to its electrical and electronic equipment law ("Elektro- und Elektronikgerätegesetz" or "ElektroG"). ${ }^{55}$ National Register for Waste Electrical 
Equipment (Stiftung Elektro-Altgeräte Register or Stiftung EAR) regulated their e-waste management and cooperates the container and pick-up facility in entire Germany. However, it is not responsible to do duty on e-waste, for example, gathering, arranging, disassembling, recycling or dumping. ${ }^{62)}$ Based on the WEEE Directive, the German government anticipates two distinct mechanisms; depending upon the transaction type, i.e. business-to-consumer (B2C) and business-to-business (B2B) transactions. Before implementing the revised ElektroG, several non-regulatory initiatives were founded in Germany, on the basis of voluntary manufacturer initiatives, which were organized to collect and recycle of EoL panels (e.g. PV CYCLE).

United Kingdom (UK) has recently experienced a rapid deployment of solar PV, though it is known as a relatively young market for PV panels. In UK, the WEEE Directive was employed in 2014 and before that, the voluntary producer initiatives (e.g. PV CYCLE) and takeback and recycle methods held by manufacturers were simultaneously operated. ${ }^{6}$ Prior to 2014, manufacturer warranties cover the most of the solar panels and so returned via the B2B approach, since limited number of PV panels were installed at that time. Furthermore, the UK WEEE regulation comprises some requisites, which are significantly different with EU WEEE Directive, for e.g., on the basis of market share, PV manufacturers are required to invest for collecting household (B2C) solar panels.

In Italy, the estimated amount for PV waste is calculated to be 2.1-8.2 million $\mathrm{t}$ by $2050 .^{14,63)}$ After the provision of WEEE Directive and according to Ministerial order in 2012, the PV panel producers in Italy have to follow the method or group of panel recycling to demonstrate the ability of long-term system. ${ }^{63)}$ The detail processes and documents that need to submit by the system or consortium were published, by the Guarantor of Electric Services (GSE), which is the Italy's national electricity organization, for demonstrating whether it is suitable to the GSE requisites. After publishing list of proper method or consortium in March 2013, PV panel producers for PV plants in the $4^{\text {th }}$ and $5^{\text {th }}$ Conto Energia (the national funding programs that came into process after 1 July 2012), must offer a verification of connection to a system or consortium to be approved feed-in tariffs. ${ }^{63)}$

\section{Solar panel recycling}

The high demand of PV solar panels in near future necessitates solutions in advance to prevent potential environmental problems. The existence of commercial-scale end-of-life-treatment (EoLT) service center for solar panels are rare, and it is still challenging technically and economically for the complete recycling of PV products. ${ }^{64)}$ As the PV panels will get to EoL in 20 to 30 years, the total volume of solar waste will forcefully drive the PV field to become more aware about the development of eco-friendly and feasible waste managing method. ${ }^{65)}$ Further, PV manufacturing and installing mostly started during 1990s decade; a large quantity of unwanted PV panels can be anticipated in this decade and thus the importance of PV waste treatment is increasing. ${ }^{64)}$ As $96 \%$ of the ingredients can be reused during manufacturing fresh panels, the recycling of solar PV will help finance the future growth of solar industry and it will create additional employment opportunities. ${ }^{14)}$ So far, without any effective management policy, the usual linear "take-make-consume-dispose" method has used in PV system will certainly challenge the renewable eminence of these tools. ${ }^{66}$ ) Thus, the industry should begin developing recycling process instead of waiting for taking action until disposing the waste. Currently, the solar modules recycling methods are developing globally, however, only a small percentage of the material and value can be recovered by existing recycling approaches. ${ }^{16)}$ The stockpiling of hazardous waste can be prevented by enabling design for environment with replacement of damaged parts or ineffective modules prior to attain their utmost life-cycle. ${ }^{67)}$

There is a lack of participation and awareness among consumers for recycling electronic waste and this kind of ignorance is most widespread within PV supply chain. ${ }^{67,68)}$ In addition, the customers and producers generally choose to dump them when recycling is expensive compared to landfill. ${ }^{49}$ In Europe, most of the PV panels being used these days will not enter the waste stream until around 2040 since the solar markets in EU did not actually take off until 2008, however, $\mathrm{PV}$ cycle in there has been working for improvement of recycling since $2007 .^{23)}$ Since 2012, PV module recycling was mandated in the EU through the WEEE Directive that comprises of various targets to collect, recover, and recycle the waste obtained through electric and electronic tools, including solar panels. ${ }^{56)}$ In EU, the annual recovery targets (mass \%) under the revised WEEE Directive, are set to $85 \%$ (for recovery) and $80 \%$ (prepared for reuse and recycled) by $2018 .{ }^{6}$ In USA, the solar panels must be managed under its common regulatory outline because definite requirement for solar panels are not included in the 'Resource Conservation and Recovery Act. ${ }^{6}$ ) However, some PV business investors in USA, provide gathering and recycling of EoL panels 
voluntarily (e.g. First Solar). ${ }^{46)}$ The developments related to PV recycling have been reviewed by a corporate social responsibility committee, which is maintained by U.S. Solar Energy Industries Association (SEIA) and announced the inauguration of a National PV Recycling Program in September 2016. Following are the PV recycling functioning group members within the SEIA: First Solar, SunPower, Flex, JinkoSolar, Panasonic, SolarCity and Trina Solar. ${ }^{56)}$ Nevertheless, the Europe only has one dedicated solar recycling plant until now. ${ }^{23)}$ There should be sufficient management guidelines for solar cells when their life span will be finished or when they are unusable any longer. Furthermore, there are a limited recycling facilities in China which involve in repairing constituents and panel dissembling and appoints an outer tools for conducting the dismantling and recycling of different constituents. $^{5)}$

The useful materials present in solar PV system can be recovered from waste PV panels. Many investigations were carried out with various processes and techniques to achieve the best recovery of the ingredients for polycrystalline silicon, amorphous silicon and CdTe PV panels. ${ }^{69-71)}$ The mechanical, thermal and chemical methods are generally used to recycle c-Si modules and after recycling process, glass, aluminum and semiconductors can be retrieved. ${ }^{16}$ The expected recovery rate of waste material is more than $95 \%$ when the waste goes again into raw matter. ${ }^{1472)}$ Ashfaq et al. ${ }^{65)}$ presented a study on comparing for old, new and recycled PV modules by using mathematical simulation. The results indicated that $90 \%$ of the things that reclaimed from the solar cells can be recycled into valuable products. Also, Sustainability Victoria reported that about $90 \%$ of the separated materials recovered from the solar panels could be recycled or reused if shredding (cutting or grinding) and heat treatment process are combined compared to either method alone or chemical treatment. ${ }^{15)}$ Furthermore, PV modules in the Europe are categorized as electronic waste under WEEE Directive with an $85 \%$ recovery target which consists of $80 \%$ reuse and recycling. ${ }^{23)}$ The PV recycling process in EU was first stablished by an organization, 'PV Cycle', which found a record recycling rate of $96 \%$ in c-Si PV modules (portion of solid recycled, transcending current EU WEEE standard) in 2016. ${ }^{73)}$ The recycling process developed by 'PV Cycle' consists of separating cables, junction box and frame from the module. After that the module is shredded, arranged and detached followed by the separating the constituents for sending to particular recycling practices related with each constituent. ${ }^{73)}$ In fact, the problems arise in making solar PV (for example, providing silicon, production costs and managing PV module) can be resolved by pure silicon retrieved from waste solar modules. ${ }^{74)}$

To prepare the secure and economical technique for disposing solar panel, recycling is attempted and recovery of such materials will keep these wastes out of the landfills, as well as keeping the valuable natural resources instead of their depletion. Nevertheless, it requires time for wide execution of recycling and also needs more investigation to find the full potential of sufficient reprocessing all constituents present in solar panel. A range of recycling options are available for solar panels, however all of them are not perfect which presents the challenges of recycling alternatives. ${ }^{23)}$ The PV technologies are regularly upgraded for recycling of all types of PV panel failures, including malfunctioning modules, glass breakage, laminate and electrical defects, wrong designs, process losses or decommissioning. ${ }^{14)}$

There are some environmental and economic aspects of the PV recycling processes, which should consider all-inclusive steps, from PV panel gathering to the end of the recycling procedure. Although there are several advantages of solar PVs, however there are also some disadvantages. A project study showed that plastic ignition and other treatments by mechanical and chemical means for retrieving metal (such as sieving, acid leaching, electrolysis, and neutralization) are the major causes for affecting environment by $\mathrm{c}-\mathrm{Si}$ recycling process. ${ }^{75)}$ The transportation and chemical processing are possible causes for generating environmental impacts. Furthermore, an additional chemical treatment is required before the use of recycled silicon from solar cells, as well as for aluminum and silver. ${ }^{16)}$ In addition, it is reported that there is no process yet which can recycle $100 \%$ of the recovered constituents from the solar panels. ${ }^{76)}$ Besides, the recycle processing of solar modules could make a prodigious monetary value for recovery of valuable materials ${ }^{77)}$ and thus extracting secondary raw ingredients from solar modules can make the available to the market once again. A preliminary estimation predicted that an overall value of substance that recovered by PV recycling can make up to USD 450 million by 2030 and about 60 million PV modules (18 GW of power generation capacity) can be manufactured, which could be $33 \%$ (approximately) of the 2015 production. ${ }^{\text {) }}$ However, it is estimated that the amount of the solar waste should keep constant in order to make PV recycling to be economically feasible. ${ }^{55)}$

Furthermore, a substantial reduction of Global Warming Potential effects (up to $20 \%$ compared to cell manufacturing 


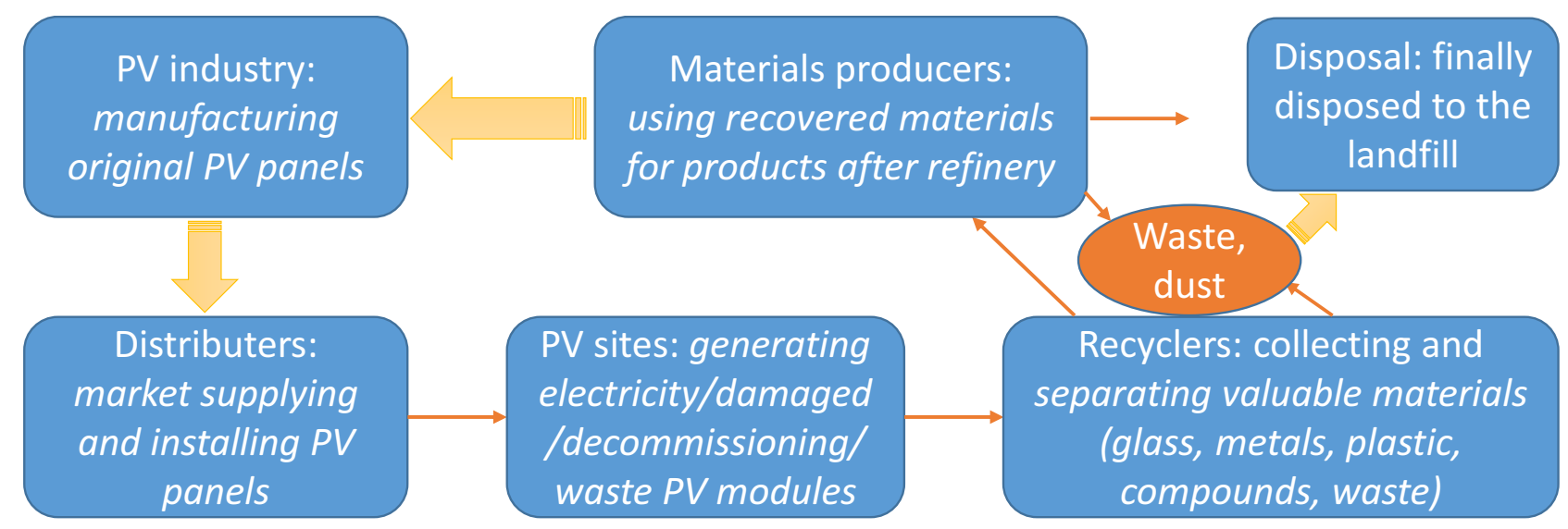

Fig. 3. General flow chart for the production, distribution and treatment of EoL PV panel.

process) was shown by the 'PV Cycle' for c-Si recycling process and an environmental advantage from the copper and glass recycling was reported. ${ }^{78)}$ Herceg et al. conducted Life Cycle Assessment (LCA) method for analysis of the environmental performances of PV system as well as waste management. ${ }^{77)}$ They have shown that there is a substantial impact of committed substance recovery on the reduction of the global warming potential of solar electricity by avoiding the emission of greenhouse gas. Also, recycling scenario showed lower influence on environment when compared to the landfill scenario during manufacturing of polysilicon, cell processing and module constructing method, since the recycled resources go back to the manufacturing PV cells and modules. ${ }^{76)}$ Even though recycling method involves disassembling, re-melting stage, thermal and chemical treating means, from which environmental problems will arise, however its influence on environment is even lower than landfill treatment.

Fig. 3 shows a general flow for the production, distribution and of the EoL treatment process of solar waste modules. At first, producers manufacture PV panels in industries and then the panels are supplied to installation sites by distributors. After deploying the PV, it generates electricity. However, after ending the life of panels, their function may be seized or the panels may got broken due to some natural or anthropogenic hazards/activities. Due to this, waste materials would be formed from solar PV panels. The important substances present within solar modules, for example, glass, metals, and their compounds are separated by carrying them to center operating by recyclers or intermediate processors of the waste solar panels used at sites and manufacturing facilities. After processing, the material manufacturers such as metal refinery companies, have utilized valuable recovered materials as secondary materials for products. ${ }^{56)}$ Nevertheless, the less valuable or non-valuable materials, including dust produced by recycler, intermediary processor, and substance producers can be dumped in the landfill sites.

The EU developed solar waste guidelines comprising PV-specific collecting, recovery and recycling aims and WEEE Directive demand all manufacturer providing solar panels to European marketplace to fund the expenses of gathering and recycling solar panels in EU states. ${ }^{5)}$ Other nations should get knowledge from EU for assisting the local development of relevant methods.

\section{Knowledge gaps and future view point}

Solar PVs will be exposed to harsh outdoor environment when they are not properly disposed out, as a result the materials in solar panels will weathered and various hazardous components (heavy metals) will be released. Although the solar panels are far better green energy source and replacement of other non-green technology, however they are suffered for toxicity of hazardous substances used and the PV material production, fabrication, handling, transportation and recycling process also generate greenhouse gases.

The reuse of solar PV panels sometimes becomes a challenging economic option since about $99 \%$ of now a days gathered end-of-life solar cells has bear some sort of handling or installation damage and in most of the cases, the glass is broken and thus cannot be exchanged or repaired economically. ${ }^{79)}$ Furthermore, the solar PV system cannot be left to accumulate as waste in a landfill if it is considered to be a genuine environmental benefit to us. ${ }^{14)}$ In future, the recycling of $\mathrm{PV}$ modules possibly will make to produce 2 billion new panels without investing into new raw materials 
because about $£ 11$ billion recoverable value will be obtained by 2050 and it will also create greener job opportunities in the world. ${ }^{14)}$ As such, the PV recycling process can reduce the potential of hazardous substances (cadmium selenium, lead) and recovering of materials and make them available for the future.

Although it is technologically possible to recycle of Solar cells waste, however it has been found that the process of recycling is expensive in comparison to landfill if there is no political helps such as producer responsibility. ${ }^{41)}$ Since, PV recycling processes have shown both the opportunities and challenges, thus there should be improvement in recycling techniques for achieving enhanced recovery rates and works on the transportation though having environmental benefits of PV recycling. In addition, the proportions of the solar cell waste stream should keep constant in order to make PV recycling to be economically feasible. If it is cheaper initial producing cost and there is increased PV waste flows, recycling PV would become economically profitable. ${ }^{9}$

It should be considered that certain materials contained in the backsheet (e.g. fluorine) for future waste material flow and landfilling of unrecovered fraction of polymers, silicon and metals can become problematic. ${ }^{77)}$ The thermal treatment should be done with great care because these treatments can be responsible for releasing hydrogen fluoride (air pollutant) that emitted from the incineration of halogenated plastics in the backsheet of solar panels. ${ }^{80)}$ In future, inspection should be done on the advantage of recycling of the entire system, together with inverter, battery and other constituents. The amounts of waste generated for PV panels and batteries are different as the EoL of PV panels and batteries going the waste cycle are diversed (i.e. usually more than 25 years and 5 years for PV and batteries respectively $)^{51)}$ and thus the treatment is required for all components of PVs to avoid the environmental impacts. Furthermore, the battery recyclers are collecting only batteries and not collecting the acids present in the battery. Right after receipt, the collectors drain the acid and thus acid together with dissolved and dispersed $\mathrm{Pb}$ is just discharge into the environment. If not disposed properly, lead sulfate used in batteries can contaminate surrounding ecosystem, which could cause serious and potentially critical health risks for human being.

On the other hand, there is dearth of instruction on how to represent the EoL stage of PV panels. The point that life cycle of a solar cell is not totally free from environmental influences, cannot be avoided because there are a little LCA studies have comprised end-of-life phase of $\mathrm{PV}^{64)}$ Regarding the assessment of the probable advantage and worries because of dispersed production from solar panels, instruction must be developed comprising suggestion for the reduction of influences due to the disassembling and gathering of waste PV panels. ${ }^{75)}$ Recently, the guidance has provided on PV-specific factors used as inputs in life cycle assessment (LCA) and on selections and assumptions in life cycle inventory (LCI) analysis and on application of modeling methods. The existing strategies hold production of electric energy with ground mounted, building attached as well as building combined solar system. They are planned to be useful on evaluating commercially installed PV technologies. ${ }^{81)}$ A pilot scale study on life cycle impact assessment (LCIA), done by Latunussa et al., showed that transportation of solar waste to the site, the burning methods, and also the metal regaining from the bottom ash (comprising sieving, acid leaching, electrolysis, neutralization and filtrations) are considered as the main contributors of all the impacts. ${ }^{75)}$ They also found that the whole climate change influence of the process amounts to around $370 \mathrm{~kg} \mathrm{CO}$ eq for recycling $1,000 \mathrm{~kg}$ of crystalline silicon PV waste, which is mainly due to transportation (29\%), the incineration of the PV sandwich (34\%) and the metal recovery cures (24\%). However, another LCA study showed that the solar cell production have a 2 time less negative environmental influence compared to environmental reprieve replacement of electricity produced in a coal-fired power plant. ${ }^{82)}$ It was also found that the small difference is observed in the 'Ecosystem category', and relatively largest difference can be seen in the 'Resources category' which means that producing electrical energy using a solar panel at last is more ecofriendly solution. On the other hand, many chemical substances are used and emitted during PV panel manufacturing, which are not environmentally neutral ${ }^{82)}$ and research should be focused on the least environmentally hostile. Thus, it is necessary to make further enhancement in the financial feasibility, pragmatism, high recovery rate and environmental performance of solar industry with respect to recycling its products.

\section{Conclusions}

The rapid increase in current solar panel installation will cause to produce a massive quantity of PV waste in nearby future. Since it is a large volume of waste which is hard to recycle, so the trouble of solar waste discarding will detonate 
with full force and wreck the environment. The waste PV has the ability to generate a perilous waste management problem because the substances present in PV panels can leak into soil and groundwater creating environmental pollution and safety concern.

There are still few challenges for solar PV module recycling such as recovery of all of the materials used in PVs, process efficiency and economic feasibility and thus it remains a complex, energy requirement process with the use of toxic materials during treatment of some substances in recycling as well as PVs manufacturing process. The funding in solar waste-related projects, for example PV recycling (reduce and/or reuse of materials), plan and observing, needs to be increased. The EoL solution should build to confirm that clean energy solutions thus not to make waste load for upcoming generation. The recovery of the EoL PV raw substances can lead to create a circular economy, which also prevents the possible environmental influences and maximize resource efficacy. The present literature review highlighted the major issues regarding solar PV wastes and treatments, which can be appropriate for policy makers and recyclers. Further study should be conducted to evaluate the possible advantages and disadvantages related to PV technology, waste management, feasible recycling pathways, and recycling of the recovered materials.

\section{Acknowledgement}

This work was supported by the National Research Foundation of Korea (NRF-2016M3A6A7945504 \& 2018M3A6A7074641).

\section{References}

1. Y. Xu, J. Li, Q. Tan, A. L. Peters, C. Yang, Global status of recycling waste solar panels: a review, Waste Manag., 75, 450-458(2018).

2. P. Nain, A. Kumar, Initial metal contents and leaching rate constants of metals leached from end-of-life solar photovoltaic waste: an integrative literature review and analysis, Renew. Sustain. Energy Rev., 119, 109592(2020).

3. IEA, World Energy Investment 2018, International Energy Agency, IEA Publications, Paris, France(2018).

4. IEA, Energy Technology Perspectives 2017: Catalysing Energy Technology Transformations, International Energy Agency, IEA Publications, Paris, France(2017).

5. M. S. Chowdhury, K. S. Rahman, T. Chowdhury, N. Nuthammachot, K. Techato, M. Akhtaruzzaman, S. K. Tiong, K. Sopian, N. Amin, An overview of solar photovoltaic panels' end-of-life material recycling, Energy Strateg. Rev., 27, 100431(2020).
6. IRENA, IEA-PVPS, End-of-life management: solar photovoltaic panels, www.irena.org, June(2020).

7. Solar Power Europe, Global market outlook for Solar Power/2018-2022, https://www.solarpowereurope.org/globalmarket-outlook-2018-2022, June(2020).

8. A. Domínguez, R. Geyer, Photovoltaic waste assessment of major photovoltaic installations in the United States of America, Renewable Energy, 133, 1188-1200(2019).

9. C. C. Faircloth, K. H. Wagner, K. E. Woodward, P. Rakkwamsuk, S. H. Gheewala, The environmental and economic impacts of photovoltaic waste management in Thailand, Resour. Conserv. Recycl., 143, 260-272(2019).

10. A. Abate, Perovskite solar cells go lead free, Joule, 1(4), 659-664(2017).

11. G. Panthi, R. Bajagain, Y.-J. An, S.-W. Jeong, Leaching potential of chemical species from real perovskite and silicon solar cells, Process Saf. Environ. Prot., 149, 115-122(2020).

12. Y. Y. Bang, N. J. Hong, D. S. Lee, S. R. Lim, Comparative assessment of solar photovoltaic panels based on metal-derived hazardous waste, resource depletion, and toxicity potentials, Int. J. Green Energy., 15(10), 550-557(2018).

13. K. Pickerel, It's time to plan for solar recycling in the United States, https://www.solarpowerworldonline.com/2018/ 04/its-time-to-plan-for-solar-panel-recycling-in-the-united-stat es/, June(2020).

14. A. T. Vekony, The opportunities of solar panel recycling, https://www.greenmatch.co.uk/blog/2017/10/the-opportunities -of-solar-panel-recycling, June(2020).

15. Suatainablity Victoria, National approach to manage solar panel, inverter and battery lifecycles, https://www.sustainability.vic. gov.au/About-us/Research/Solar-energy-system-lifecycles, $\operatorname{July}(2020)$.

16. M. M. Lunardi, J. P. Alvarez-Gaitan, J. I. Bilbao, R. Corkish, A review of recycling processes for photovoltaic modules, Solar Panels and Photovoltaic Materials, B. Zaidi (Ed.), IntechOpen, London, United Kingdom(2018).

17. I. Celik, Z. Song, A. B. Phillips, M. J. Heben, D. Apul, Life cycle analysis of metals in emerging photovoltaic (PV) technologies: a modeling approach to estimate use phase leaching, J. Clean. Prod., 186, 632-639(2018).

18. P. Nain, A. Kumar, Identifying issues in assessing environmental implications of solar PVs-related waste, Recent Developments in Waste Management, A. Kalamdhad (Ed.), Springer, Singapore, pp. 71-90(2020).

19. A. Chen, More solar panels mean more waste and there's no easy solution, https://www.theverge.com/2018/10/25/180188 20/solar-panel-waste-chemicals-energy-environment-recycling, October(2020).

20. B. Wirtz, Solar panels produce tons of toxic waste-literally, https://fee.org/articles/solar-panels-produce-tons-of-toxic-wast e-literally/, June(2020).

21. J. Dini, Solar panel waste: a disposal problem, watts up with that?, https://wattsupwiththat.com/2018/12/23/solar-panel-waste -a-disposal-problem/, October(2020).

22. R. Zapf-Gottwick, M. Koch, K. Fischer, F. Schwerdt, L. 
Hamann, M. Kranert, J. W. Metzger, J. H. Werner, Leaching hazardous substances out of photovoltaic modules, Int. J. Adv. Appl. Phys. Res., 2, 7-14(2015).

23. J. Deign, Landfilling old solar panels likely safe for humans, new research suggests, https://www.greentechmedia.com/articles /read/solar-panel-landfill-deemed-safe-as-recycling-optionsgrow, June(2020).

24. S. A. Robinson, G. A. Meindl, Potential for leaching of heavy metals and metalloids from crystalline silicon photovoltaic systems, J. Nat. Resour. Dev., 9, 19-24(2019).

25. G. A. Engwa, P. U. Ferdinand, F. N. Nwalo, M. N. Unachukwu, Mechanism and health effects of heavy metal toxicity in humans, Poisoning in the Modern World - New Tricks for an Old Dog?, O. Karcioglu, B. Arslan (Eds.), IntechOpen, London, United Kingdom(2019).

26. M. Jaishankar, T. Tseten, N. Anbalagan, B. B. Mathew, K. N. Beeregowda, Toxicity, mechanism and health effects of some heavy metals, Interdiscip. Toxicol., 7(2), 60-72(2014).

27. H. Needleman, Lead poisoning, Annu. Rev. Med., 55, 209-222(2004).

28. M. A. Tranel, R. O. Kimmel, Impacts of lead ammunition on wildlife, the environment, and human health-a literature review and implications for Minnesota, Ingestion of Lead from Spent Ammunition: Implications for Wildlife and Humans, R. T. Watson, M. Fuller, M. Pokras, W. G. Hunt (Eds.), The Peregrine Fund, Idaho, USA(2009).

29. M. Chakankar, C. H. Su, H. Hocheng, Leaching of metals from end-of-life solar cells, Environ. Sci. Pollut. Res. Int., 26(29), 29524-29531(2019).

30. J. M. Kadro, A. Hagfeldt, The end-of-life of perovskite PV, Joule, 1(1), 29-46(2017).

31. Solar Waste, In your country - solar waste / European WEEE Directive, http://www.solarwaste.eu/in-your-country/, October(2020).

32. P. Sinha, A. Wade, Assessment of leaching tests for evaluating potential environmental impacts of PV module field breakage, IEEE J. Photovoltaics, 5(6), 1710-1714(2015).

33. A. Finke, A. Kriele, W. Thumm, D. Bieniek, A. Kettrup, Leaching tests with thin film solar cells based on copper indium diselenide (CIS), Chemosphere, 32(8), 1633-1641(1996).

34. A. Ramos-Ruiz, J. V. Wilkening, J. A. Field, R. Sierra-Alvarez, Leaching of cadmium and tellurium from cadmium telluride (CdTe) thin-film solar panels under simulated landfill conditions, J. Hazard. Mater., 336, 57-64(2017).

35. P. Sinha, R. Balas, L. Krueger, A. Wade, Fate and transport evaluation of potential leaching risks from cadmium telluride photovoltaics, Environ. Toxicol. Chem., 31(7), 1670-1675(2012).

36. C. Zeng, A. Ramos-Ruiz, J. A. Field, R. Sierra-Alvarez, Cadmium telluride (CdTe) and cadmium selenide (CdSe) leaching behavior and surface chemistry in response to $\mathrm{pH}$ and $\mathrm{O}_{2}$, J. Environ. Manage., 154, 78-85(2015).

37. J. Nover, R. Zapf-Gottwick, C. Feifel, M. Koch, J. W. Metzger, J. H. Werner, Long-term leaching of photovoltaic modules, Jpn. J. Appl. Phys., 56, 08MD02(2017).
38. V. Savvilotidou, A. Antoniou, E. Gidarakos, Toxicity assessment and feasible recycling process for amorphous silicon and CIS waste photovoltaic panels, Waste Manag., 59, 394-402(2017).

39. P. Su, Y. Liu, J. Zhang, C. Chen, B. Yang, C. Zhang, X. Zhao, Pb-based perovskite solar cells and the underlying pollution behind clean energy: dynamic leaching of toxic substances from discarded perovskite solar cells, J. Phys. Chem. Lett., 11(8), 2812-2817(2020).

40. L.-T. Lu, Photovoltaic waste management and implementing extended producer responsibility in the solar industry in California, San Jose State University(2019).

41. N. C. McDonald, J. M. Pearce, Producer responsibility and recycling solar photovoltaic modules, Energy Policy, 38(11), 7041-7047(2010).

42. J. K. Choi, V. Fthenakis, Crystalline silicon photovoltaic recycling planning: macro and micro perspectives, J. Clean. Prod., 66, 443-449(2014).

43. OECD, Extended Producer Responsibility: A Guidence Manual for Governments, Organisation for Economic Co-operation and Development (OECD) Publishing, Paris(2001).

44. K. Larsen, End-of-life PV: then what?-recycling solar PV panels, Renew. Energy Focus, 10, 48-53(2009).

45. WEEE Directive, Producers: definition and obligations, http://www.solarwaste.eu/pv-waste-legislation/producers/, November(2020).

46. A. Sharma, S. Pandey, M. Kolhe, Global review of policies \& guidelines for recycling of solar PV modules, Int. J. Smart Grid Clean Energy, 8(5), 597-610(2019).

47. M. Shellenberger, If solar panels are so clean, why do they produce so much toxic waste?, https://www.forbes.com/sites /michaelshellenberger/2018/05/23/if-solar-panels-are-so-clean -why-do-they-produce-so-much-toxic-waste/\#2f459730121c, June(2020).

48. J. Singh, A. S. Kalamdhad, Effects of heavy metals on soil, plants, human health and aquatic life, Int. J. Res. Chem. Environ., 1, 15-21(2011).

49. M. Besiou, L. N. Van Wassenhove, Closed-loop supply chains for photovoltaic panels: a case-based approach, J. Ind. Ecol., 20(4), 929-937(2016).

50. S. Mahmoudi, N. Huda, M. Behnia, Photovoltaic waste assessment: forecasting and screening of emerging waste in Australia, Resour. Conserv. Recycl., 146, 192-205(2019).

51. Factor, PV/battery waste management in the context of rural electrification, https://www.wearefactor.com/docs/PV-Battery _Waste_Management.pdf, August(2020).

52. E. Hsu, C. M. Kuo, A recycling system for sustainable management of waste solar photovoltaic panels in Taiwan, Energy Technology 2020: Recycling, Carbon Dioxide Management, and Other Technologies, X. Chen, Y. Zhong, L. Zhang, J. A. Howarter, A. A. Baba, C. Wang, Z. Sun, M. Zhang, E. Olivetti, A. Luo, A. Powell (Eds.), Springer, pp. 241-248(2020).

53. METI, 11th new and renewable energy subcommittee under the committee on energy efficiency and renewable energy 
subcommittee, Ministry of Economy, Trading and Industry (METI), Tokyo(2015).

54. METI and MOE, Report on reuse, recycling and proper treatment of EOL renewable energy equipment, METI and Ministry of Environment (MOE), Tokyo(2015).

55. H. Kim, H. Park, PV waste management at the crossroads of circular economy and energy transition: the case of South Korea, Sustainability, 10, 3565(2018).

56. IEA-PVPS, End-of-life management of photovoltaic panels: trends in PV module recycling technologies, https://iea-pvps.org/ wp-content/uploads/2020/01/End_of_Life_Management_of_P hotovoltaic_Panels_Trends_in_PV_Module_Recycling_Techn ologies_by_task_12.pdf, October(2020).

57. ESSB 5939, Promoting a sustainable, local renewable energy industry through modifying renewable energy system tax incentives and providing guidance for renewable energy system component recycling, https://legiscan.com/WA/text/ SB5939/id/1641729, October(2020).

58. Legislative Counsel's Digest, Hazardous waste: photovoltaic modules, https://leginfo.legislature.ca.gov/faces/billNavClient. xhtml?bill_id=201520160SB489, October(2020).

59. European Commission, Frequently asked questions on Directive 2012/19/EU on Waste Electrical and Electronic Equipment, https://ec.europa.eu/environment/waste/weee/pdf/ faq.pdf, October(2020).

60. The European Parliament and Council of the EU, Directive 2002/96/EC of the European Parliament and of the Council of 27 January 2003 on Waste Electrical and Electronic Equipment (WEEE), https://eur-lex.europa.eu/resource.html? uri=cellar:ac89e64f-a4a5-4c13-8d96-1fd1 d6bcaa49.0004.02/ DOC_1\&format=PDF, October(2020).

61. The European Parliament and Council of the EU, Directive 2012/19/ EU of the European Parliament and of the Council of 4 July 2012 on Waste Electrical and Electronic Equipment (WEEE), https://eur-lex.europa.eu/legal-content/ EN/TXT/PDF/?uri=CELEX:32012L0019\&from=EN, October (2020).

62. Stiftung EAR, Stiftung Elektroaltgeräte Register, Stiftung Elektroaltgeräte (Used Electronic Equipment), www.stiftung-ear. de/en/, October(2020).

63. A. Paiano, Photovoltaic waste assessment in Italy, Renew. Sustain. Energy Rev., 41, 99-112(2015).

64. J. Tao, S. Yu, Review on feasible recycling pathways and technologies of solar photovoltaic modules, Sol. Energy Mater. Sol. Cells., 141, 108-124(2015).

65. H. Ashfaq, I. Hussain, A. Giri, Comparative analysis of old, recycled and new PV modules, J. King Saud Univ. - Eng. Sci., 29(1), 22-28(2017).

66. D. Sica, O. Malandrino, S. Supino, M. Testa, M. C. Lucchetti, Management of end-of-life photovoltaic panels as a step towards a circular economy, Renew. Sustain. Energy Rev., 82(3), 2934-2945(2018).

67. H. K. Salim, R. A. Stewart, O. Sahin, M. Dudley, Drivers, barriers and enablers to end-of-life management of solar photovoltaic and battery energy storage systems: a systematic literature review, J. Clean. Prod., 211, 537-554(2019).

68. P. Tanskanen, Management and recycling of electronic waste, Acta Mater., 61(3), 1001-1011(2013).

69. W. D. Cyrs, H. J. Avens, Z. A. Capshaw, R. A. Kingsbury, J. Sahmel, B. E. Tvermoes, Landfill waste and recycling: use of a screening-level risk assessment tool for end-of-life cadmium telluride (CdTe) thin-film photovoltaic (PV) panels, Energy Policy, 68, 524-533(2014).

70. G. Granata, F. Pagnanelli, E. Moscardini, T. Havlik, L. Toro, Recycling of photovoltaic panels by physical operations, Sol. Energy Mater. Sol. Cells, 123, 239-248(2014).

71. M. Marwede, W. Berger, M. Schlummer, A. Mäurer, A. Reller, Recycling paths for thin-film chalcogenide photovoltaic waste - current feasible processes, Renew. Energy., 55, 220-229(2013).

72. Veolia, A $95 \%$ recovery rate: when waste turns back into raw materials, https://www.veolia.com/en/newsroom/news/ recycling-photovoltaic-panels-circular-economy-france, June(2020).

73. PV CYCLE, Breakthrough in PV module recycling, http://www.pvcycle.org/press/breakthrough-in-pv-module-rec ycling/, August(2020).

74. S. Kang, S. Yoo, J. Lee, B. Boo, H. Ryu, Experimental investigations for recycling of silicon and glass from waste photovoltaic modules, Renew. Energy, 47, 152-159(2012).

75. C. E. L. Latunussa, F. Ardente, G. A. Blengini, L. Mancini, Life cycle assessment of an innovative recycling process for crystalline silicon photovoltaic panels, Sol. Energy Mater. Sol. Cells., 156, 101-111(2016).

76. B. Huang, J. Zhao, J. Chai, B. Xue, F. Zhao, X. Wang, Environmental influence assessment of China's multicrystalline silicon (multi-Si) photovoltaic modules considering recycling process, Sol. Energy, 143, 132-141(2017).

77. S. Herceg, S. P. Bautista, K.-A. Weiß, Influence of waste management on the environmental footprint of electricity produced by photovoltaic systems, Energies, 13(9), 2146 (2020).

78. J. R. Perez-Gallardo, C. Azzaro-Pantel, S. Astier, A multiobjective framework for assessment of recycling strategies for photovoltaic modules based on life cycle assessment, Waste Biomass Valorization, 9, 147-159(2018).

79. Solar Waste, Collection \& recycling - Solar Waste / European WEEE Directive, http://www.solarwaste.eu/collection-andrecycling/, October(2020).

80. F. Ardente, C. E. L. Latunussa, G. A. Blengini, Resource efficient recovery of critical and precious metals from waste silicon PV panel recycling, Waste Manag., 91, 156-167(2019).

81. IEA-PVPS, Methodology guidelines on life cycle assessment of photovoltaic 2020, https://iea-pvps.org/key-topics/methodo logy-guidelines-on-life-cycle-assessment-of-photovoltaic-2020/, October(2020).

82. M. Bogacka, K. Pikoń, M. Landrat, Environmental impact of PV cell waste scenario, Waste Manag., 70, 198-203(2017). 


\section{Authors}

\section{Rishikesh Bajagain}

Department of Environmental Engineering, Kunsan National University, Ph.D. Student, ORCID (1) 0000-0002-9550-5006

\section{Gayatri Panthi}

Department of Environmental Engineering, Kunsan National University, Ph.D. Student, ORCID (1) 0000-0002-1273-4744

\section{Youn-Joo An}

Department of Environmental Health Science, Konkuk University, Professor, ORCID (이 0000-0002-0193-1929

\section{Seung-Woo Jeong}

Department of Environmental Engineering, Kunsan National University, Professor, ORCID (1) 0000-0001-7418-4576 